\title{
Decentralisation and State-sponsored Community Forestry in Asia
}

$\begin{array}{lll}\text { Editors } & : \begin{array}{l}\text { Henry Scheyvens, Kimihiko Hyakumura, and } \\ \text { Yoshiki Seki }\end{array} \\ \text { Publisher : } & \text { Institute for Global Environmental Strategies } \\ & \text { (IGES), Japan } \\ \text { Year } \quad: & 2007 \\ \text { Pages } \quad: & 120+\text { xiv } \\ \text { ISBN } \quad: \text { 4-88788-031-6 }\end{array}$

This book is the outcome of the study on the transitions in forest governance in seven countries viz. India, Nepal, Cambodia, the Philippines, Thailand, Viet Nam and China conducted by the Forest Conservation Project of the Institute for Global Environmental Strategies (IGES).

It includes eight chapters : Chapter 1 is all about the introduction while the rest of the Chapters deal with the individual studies in the seven countries. The Introductory Chapter on "Forest Governance in a State of Transition" by Henry Scheyvens, Kimihiko Hyakumura, and Yoshiki Seki has been categorized into three parts viz. Part A, Part B and

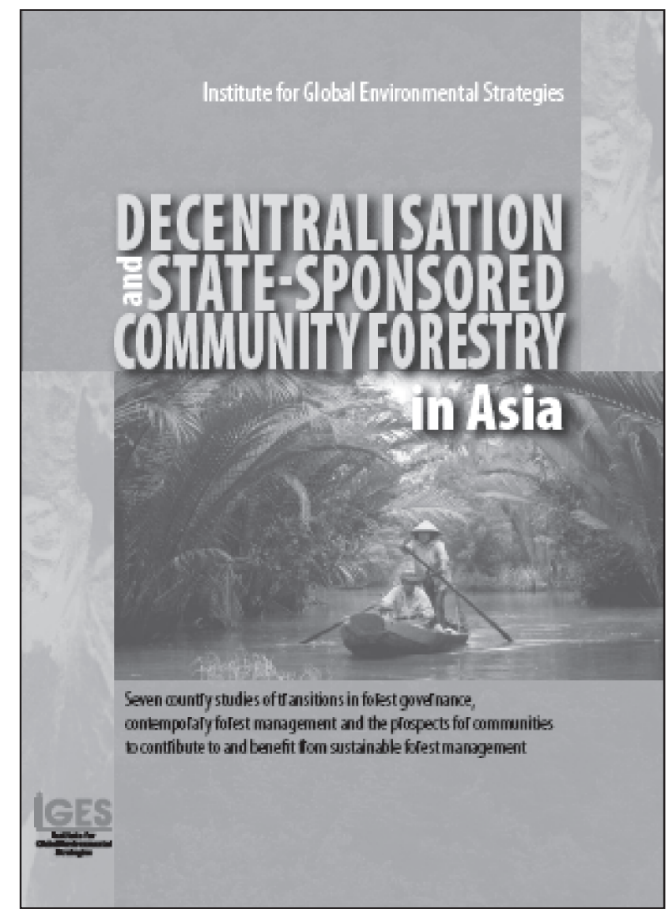
Part C. Part A describes historical context of forest governance transition, provides a concept of good governance, explains the elements of the transition and finally illustrates rationale and research methodology of the study. Similarly, Part B provides summary of the individual country studies. Likewise, Part C highlights the progress and shortcomings of the approach in seven country studies as well as suggests recommendations.

The individual country chapter analyses history of forest management, forest governance at present, decentralization and community forestry policies and their impacts. Case studies of each country illustrate the transitions in forest governance at the local level. Each Chapter concludes with policy recommendations to improve forest governance (decentralization processes and formal community forestry programs) to attain sustainable forest management in the concerned country. For instance, Chapter 3 on "Good Forest Governance in Nepal" by K.R. Kanel provides overview of good forest governance, political and socioeconomic situation, policies and institutions for forest management, decentralization of forest management with examples of different participatory forest management models and comprehensive description on community forestry. He has presented a case study of the 'Ghorlas Community Forest User Group' in Western Nepal as an illustration of good governance in community forestry. Finally, some recommendations have been suggested to improve forest governance in Nepal.

There is no question that the book is a timely and welcome addition to the growing body of literature evaluating forest governance in transition. All the chapters on the comprehensive studies written by a large number of international authors highlight the transitions in the forest governance in the seven Asian countries, and provide policy recommendations for sustainable forest management in the countries. The reference section of each chapter adds to the value of the Book. With a wide-ranging insight into different forest management approaches in Asian countries in a single volume, this book is indeed best suited as a useful reference for researchers, managers, and practitioners in the field of forestry and rural development.

\section{Shiva Khanal}

Depaertment of Forest Research and Survey

Babarmahal, Kathmandu 